\begin{tabular}{|c|c|}
\hline $\begin{array}{l}\text { MUYOVIC } \\
\text { MANAUEMEN } \\
\text { KEWIRAUSAHAAN }\end{array}$ & $\begin{array}{rr}\text { p-ISSN 1858-1048 } & \text { e-ISSN 2654-9247 } \\
\text { http://ejurnal.stieipwija.ac.id/index.php/jmk } \\
\text { DOI: http://dx.doi.org/10.33370/jmk.v17i2.464 } \\
\text { Jurnal Manajemen Kewirausahaan Vol. 17 No. 02- Des } 2020 \\
\text { Submit: } 21 \text { Okt 2020; Review: 23 Nov 2020; Publish: } 30 \text { Des } 2020\end{array}$ \\
\hline
\end{tabular}

\title{
FAKTOR YANG MEMPENGARUHI RETURN SAHAM PERUSAHAAN PROPERTI DALAM INDEKS SAHAM SYARIAH INDONESIA
}

\section{(FACTORS AFFECTING RETURN OF SHARES OF PROPERTY COMPANIES IN INDEKS SAHAM SYARIAH INDONESIA)}

\author{
Oleh: \\ Angga Presetia ${ }^{1)}$; Nurmala Ahmar ${ }^{2}$; J.M.V. Mulyadi ${ }^{3}$; Suyanto4) \\ angga.prasetia046@gmail.com ${ }^{1)}$;nurmalaahmar@gmail.com ${ }^{2}$; $;$ mulyadijmv@gmail.com $\left.{ }^{3}\right)$; \\ suyanto.ipwija@gmail.com ${ }^{4}$ \\ Universitas Pancasila1, ${ }^{1,23)}$; Sekolah Tinggi Ilmu Ekonomi IPWI Jakarta4)
}

\begin{abstract}
ABSTRAK
Studi ini bertujuan untuk meneliti sejauh mana rasio keuangan mempengaruhi return saham pada perusahaan properti, real estate, dan building contruction yang memiliki saham berbasis syariah dan tergabung dalam Indeks Saham Syariah Indonesia (ISSI) di Bursa Efek Indonesia periode 2016-2018. Metode penelitian yang digunakan dalam penelitian ini adalah metode deskriptif dan pengujian hipotesis menggunakan analisis regresi berganda dengan variabel current ratio, total asset turnover, price earning ratio, dan debt to equity ratio sebagai variabel independen. Hasil penelitian selama tiga tahun diperoleh hasil yang signifikan pada tingkat signifikansi pada kedua variabel independen tersebut terhadap varabel dependennya. Kontribusi penelitian ini adalah pembahasan hasil penelitian yang berbeda dengan hasil penelitian terdahulu dan teori yang terkait.
\end{abstract}

Kata kunci: Current Ratio; Debt to Equity Ratio; Price Earning Ratio, Return Saham; Total Asset Turnover

\begin{abstract}
This study aims to determine the extent to which financial ratios affect stock returns in property, real estate and building construction companies that have sharia-based shares and are included in the Indonesian Sharia Stock Index (ISSI) on the Indonesia Stock Exchange for the period 2016-2018. The research method used in this research is descriptive method and hypothesis testing using multiple analysis with the variables are current ratio, total asset turnover, price earning ratio, and debt to equity ratio as independent variables. The results of the three years study obtained significant results at the level of significance of the two variables independent of the dependent variable. The contribution of this study is the discussion of research results that are different from previous research results and related theories.
\end{abstract}

Keywords: Current Ratio; Debt to Equity Ratio; Price Earning Ratio; Stock Returns; Total Asset Turnover

Jurnal Manajemen Kewirausahaan Vol. 17 No. 02 - Desember 2020

LP2M Sekolah Tinggi Ilmu Ekonomi IPWI Jakarta 


\section{PENDAHULUAN}

Return merupakan salah satu prioritas rata-rata investor dalam berinvestasi. Return atau hasil investasi merupakan tingkat keuntungan yang didapatkan investor dalam berinvestasi. Adapun return dibagi menjadi dua jenis, yaitu return ekspetasi dan return realisasi. Dalam investasi asset financial para investor juga memiliki keinginan memperoleh return. Investasi asset financial menunjukkan para investor bersedia menyediakan sejumlah dana sekarang untuk memperoleh sebuah aliran dana pada masa yang akan datang sebagai kompensasi atas faktor waktu selama dana diinvestasikan dan risiko yang tertanggung. Dengan demikian para investor sedang mempertaruhkan suatu nilai sekarang untuk sebuah nilai yang diharapkan pada masa yang akan datang. Dalam penelitian-penelitian terdahulu banyak penelitian tentang faktor yang mempengaruhi naik turunnya return saham dan menghasilkan hasil penelitian yang bebeda-beda, sehingga perlu dipelajari dan dibuktikan secara empiris mengenai faktor yang mempengaruhi return saham.

Demi memperoleh Return yang maksmial para investor dalam asset financial mengadakan analisis dan upaya tindakan-tindakan berkaitan dengan investasi dalam sahamnya, agar Return yang maksmimal dapat terwujud.

Investor akan melakukan penelitian terlebih dahulu terhadap kinerja perusahaan untuk memperkirakan tingkat pengembalian (rate of return) yang akan didapat. Tinggi rendahnya harga saham dipasar modal, ditentukan oleh kinerja keuangan. Sehingga kinerja perusahaan juga menentukan return saham. Maka investor perlu melakukan pengukuran kinerja keuangan perusahaan, yang dilakukan sendiri ataupun dengan bantuan pihak lain yaitu broker atau pialang.

Melakukan analisis rasio keuangan menjadi alternatif untuk mengetahui apakah informasi keuangan yang dihasilkan perusahaan di masa yang akan datang sudah dapat bermanfaat untuk memprediksi harga atau return saham di pasar modal, Bila penyusunan laporan keuangan disusun secara baik dan akurat dapat memberikan gambaran keadaan yang nyata mengenai hasil atau prestasi yang telah dicapai oleh suatu perusahaan dalam kurun waktu tertentu.

Ekonomi syariah di Indonesia saat ini mengalami pertumbuhan yang cukup pesat, hal ini diperkuat dengan adanya persatuan umat Islam yang berlomba lomba mendirikan usaha yang berbasis syariah. Setelah melihat kesuksesan usaha syariah yang tumbuh begitu pesat dengan sistem syariahnya, mendorong beberapa sektor usaha lainnya ikut menerapkan sistem syariah pada sistem keuangannya, seperti pegadaian, asuransi, dan pasar modal.

Indonesia adalah suatu negara dengan penduduk yang mayoritas beragama Islam, telah memiliki indeks pasar modal berbasis syariah, pada tahun 2011 tepatnya pada tanggal 12 bulan Mei Bapepam-LK dan Dewan Syariah Nasional Majelis Ulama Indonesia (DSN-MUI) menerbitkan salah satu indeks harga saham syariah yaitu Indeks Saham Syariah Indonesia (ISSI).

Banyak masyarakat muslim yang beralih dari saham konvesional menjadi saham syariah hal tersebut dapat dilihat dari perkembangan return saham pada emiten yang tergabung dalam ISSI dari tahun 2016-2018.

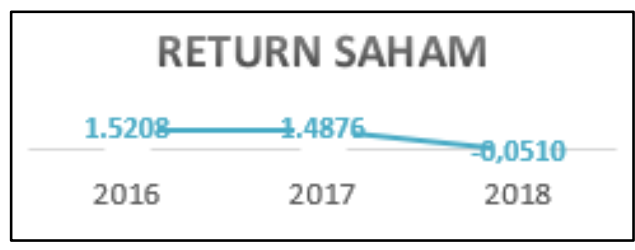

Gambar 1. Return Saham

Hasil penelitian ini dapat memperkuat hasil penelitian-penelitian terdahulu akan pengaruh faktor rasio keuangan emiten yang tergabung dalam Indeks Saham Syariah Indonesia terhadap return saham syariahnya.

\section{TUJUAN PENELITIAN}

Tujuan penelitian ini adalah guna mengetahui faktor rasio keuangan yang 
mempengaruhi return saham syariah pada emiten yang tergabung dalam ISSI.

\section{TELAAH LITERATUR DAN PENGEMBANGAN HIPOTESIS}

Return saham adalah suatu tujuan para investor dalam menginvestasikan uangnya ke dalam saham-saham yang beredar. Menurut Jogiyanto (2009) return merupakan hasil yang diperoleh dari suatu investasi. Return dapat berupa return realisasi yang sudah terjadi atau return ekspektasi yang belum terjadi tetapi diharapkan akan terjadi di masa yang akan datang.

Hanafi (2009) mengemukakan bahwa current ratio merupakan perbandingan antara aktiva lancar dan kewajiban lancar. Rasio ini merupakan ukuran yang digunakan untuk mengetahui kesanggupan suatu perusahaan memenuhi kewajiban jangka pendeknya. Current ratio menunjukkan sejauh mana perusahaan menutupi kewajiban lancar dengan menggunakan akitva lancar. Hasil perbandingan antara aktiva lancar dan kewajiban lancar semakin besar maka dapat dikatakan semakin tinggi kemampuan (semakin mampu) perusahaan menutupi kewajiban jangka pendeknya. Hasil current ratio yang rendah menunjukkan terjadinya masalah dalam likuidasi, sebaliknya jika hasil current ratio yang terlalu tinggi juga kurang baik, hal ini menunjukkan banyaknya dana menganggur yang pada akhirnya dapat mengurangi kemampuan perusahaan.

Total asset turnover merupakan bagian dari rasio aktivitas yang mengukur keefisienan dan kefektivitasan seluruh aktiva yang digunakan oleh perusahaan dalam meningkatkan nilai penjualan yang dihasilkan dari tiap rupiah aktiva dengan perbandingan antara penjualan dengan total aset (Anggraeni 2019). Efektivitas perusahaan menggunakan keseluruhan aktiva untuk menciptakan penjualan dalam kaitannya mendapatkan laba ditunjukan oleh perputaran total aktiva. Semakin efektif perusahaan menggunakan aktiva untuk memperoleh penjualan diharapkan laba perusahaan yang diperoleh semakin baik. Kinerja perusahaan yang semakin baik mencerminkan dampak pada harga saham perusahaan tersebut akan semakin tinggi dan harga saham yang tinggi memberikan return yang semakin besar. Sehingga tedapat hubungan TATO dengan return saham.

Kesediaan investor membayar lembar saham dalam jumlah tertentu dengan mengharapkan memperoleh laba perusahaan digambarkan oleh Price Earning Ratio (PER). Tingginya nilai rasio ini menandakan dana yang telah dikeluarkan investor dimana para investor meyakini bahwa perusahaan memiliki pertumbuhan yang tinggi, yang tentunya akan berdampak terhadap perolehan keuntungan (return) yang besar juga untuk investor dan pertumbuhan dan kinerja perusahaan cukup baik, ditandai dengan tinggnya nilai rasio (PER)

Kinerja perusahaan yang dipengaruhi oleh Debt to equity ratio (DER) menyebabkan apresiasi harga saham. Nilai DER yang terlalu tinggi berdampak buruk terhadap kinerja perusahaan, dikarenakan hutang yang semakin tinggi menunjukkan beban bunga perusahaan akan semakin besar dan mengurangi keuntungan. Sehingga semakin tinggi hutang (DER) cenderung menurunkan return saham.

\section{Pengaruh Current Ratio terhadap Return Saham}

Current ratio adalah rasio yang mengukur kinerja keuangan necara likuiditas perusahaan. Rasio lancar ini menunjukan kemampuan perusahaan untuk memenuhi kewajiban hutang jangka pendeknya pada 12 bulan ke depan, semakin tinggi rasio lancarnya, semakin likuid perusahaannya menyebabkan investor semakin percaya akan kelancaran jalannya perusahaan dan investor semakin tertarik untuk menanamkan dana ke dalam perusahaan tersebut, hal tersebut sesuai dengan penelitian yang dilakukan oleh Erari (2014), Sulaiman (2015), Hidayat \& Indrihastuti (2016), Hasibuan (2018), Raningsih \& Putra (2015), dan Asmi (2014). 
H1: current ratio berpengaruh terhadap return saham.

\section{Pengaruh Total Asset Turnover terhadap Return Saham}

Total asset turnover merupakan rasio yang digunakan untuk mengukur seberapa efisiensi seluruh aktiva perusahaan digunakan untuk menunjang kegiatan penjualan Efektivitas perusahaan menggunakan keseluruhan aktiva untuk menciptakan penjualan dalam kaitannya mendapatkan laba ditunjukan oleh perputaran total aktiva. Semakin efektif perusahaan menggunakan aktiva untuk memperoleh penjualan diharapkan laba perusahaan yang diperoleh semakin baik. Kinerja perusahaan yang semakin baik mencerminkan dampak pada harga saham perusahaan tersebut akan semakin tinggi dan harga saham yang tinggi memberikan return yang semakin besar. Sehingga tedapat hubungan TATO dengan return saham. Hal tersebut sesuai dengan penelitian yang dilakukan oleh Hasibuan (2018) dan Asmi (2014).

H2: Total asset turnover berpengaruh terhadap return saham.

\section{Pengaruh Price Earning Ratio terhadap Return Saham}

Kesediaan investor membayar lembar saham dalam jumlah tertentu dengan mengharapkan memperoleh laba perusahaan digambarkan oleh Price Earning Ratio (PER). Tingginya nilai rasio ini menandakan dana yang telah dikeluarkan investor dimana para investor meyakini bahwa perusahaan memiliki pertumbuhan yang tinggi, yang tentunya akan berdampak terhadap perolehan keuntungan (return) yang besar juga untuk investor dan pertumbuhan dan kinerja perusahaan cukup baik, Investor akan tertarik untuk melalukan investasi di perusahaan karena melihat hal ini. Pernyataan ini sejalan dengan hasil penelitian yang dilakukan Andansari, et al. (2016), Mutia \& Martaseli (2018), Dewi (2017), Dewi et al. (2016), Sodikin \& Wuldani (2017)

H3: price earning ratio berpengaruh terhadap return saham.

\section{Pengaruh Debt to equity ratio terhadap Return Saham}

Para investor cenderung menghindari saham-saham yang memiliki DER yang tinggi, karena tingginya nilai DER menunjukkan bahwa struktur permodalan usaha lebih banyak memanfaatkan hutang-hutang relatif terhadap ekuitas. Semakin tinggi DER mencerminkan risiko perusahaan yang relatif tinggi.

Kinerja perusahaan yang dipengaruhi oleh Debt to equity ratio (DER) menyebabkan apresiasi harga saham. Nilai DER yang terlalu tinggi berdampak buruk terhadap kinerja perusahaan, dikarenakan hutang yang semakin tinggi menunjukkan beban bunga perusahaan akan semakin besar dan mengurangi keuntungan. Sehingga semakin tinggi hutang (DER) cenderung menurunkan return saham. Hal tersebut sesuai dengan penelitian yang dilakukan oleh Sutriani (2014), Erari (2014), Hidayat \& Nur (2016) Basalama et al. (2017), Raningsih \& Putra (2015), Handayati \& Zulyanti (2018), Asmi (2014), Ramadhan (2017), Putriani \& Sukartha (2014).

H4: debt to equity ratio berpengaruh terhadap return saham.

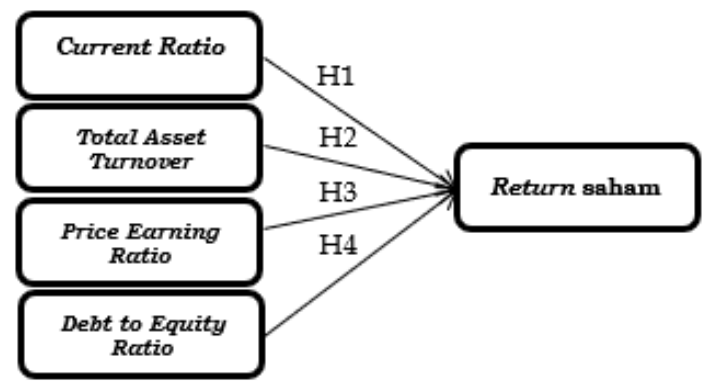

Gambar 2. Kerangka Pemikiran

\section{METODE PENELITIAN \\ Sampel Penelitian}

Penelitian ini menggunakan populasi seluruh perusahaan properti yang tergabung dalam Indeks Saham Syariah Indonesia (ISSI) terdaftar di Bursa Efek Indonesia (BEI) tahun 2016-2018. Teknik yang dilakukan dalam penelitian ini adalah purposive sampling yaitu cara pengambilan sampel yang didasarkan pada pertimbangan-pertimbangan 
tertentu yang telah ditetapkan oleh peneliti, berikut kriteria-kriteria pengambilan sampel dalam penelitian ini: 1) Perusahaan properti yang tergabung dalam Indeks Saham Syariah Indonesia periode pengamatan 2016 2018. 2) Perusahaan properti yang konsisten mempublikasikan laporan keuangan tahunan periode 2014-2018. 3) Perusahaan yang menyajikan laporan keuangan dalam satuan Rupiah (Rp).

\section{Desain Penelitian}

Penelitian ini dilakukan untuk mengetahui sejauh mana pengaruh faktor fundamental perusahaan yaitu Current Ratio (CR), Total Asset Trunover (TATO), Price Earning Ratio (PER), dan Debt to Equity Ratio (DER) terhadap return saham.

Metode yang digunakan dalam penelitian adalah metode deskriptif dan pengujian hipotesis. Return saham perusahaan yang merupakan dependen yang menjadi sampel dalam penelitian dihubungkan dengan faktor independen perusahaan yaitu Current Ratio (CR), Total Asset Trunover (TATO), Price Earning Ratio (PER), dan Debt to Equity Ratio (DER). Kategori penelitian yang dilakukan dalam penelitian ini adalah penelitian kuantitatif untuk menguji hipotesis penelitian.

\section{Operasionalisasi Variabel}

Operasionalisasi variabel penelitian dapat dikemukakan sebagai berikut:

Tabel 1. Operasionalisasi Variabel

\begin{tabular}{|c|c|c|c|c|}
\hline Variabel & Definisi & Durmeus & $\begin{array}{l}\text { Scala } \\
\text { Pengularan }\end{array}$ & Refrensi \\
\hline \multicolumn{5}{|l|}{ Dependen } \\
\hline Return Saham & $\begin{array}{l}\text { Hasil Jang } \\
\text { diperoleh dari } \\
\text { lnivestasi }\end{array}$ & $\frac{P_{t}-P t-1+D t}{P t-1}$ & Rasio & $\begin{array}{l}\text { Fairi dam } \\
\text { Dewi. } \\
\text { (2018) }\end{array}$ \\
\hline \multicolumn{5}{|l|}{ Independen } \\
\hline$c r$ & $\begin{array}{l}\text { Rasio yang } \\
\text { membag altiva } \\
\text { lancar dengan } \\
\text { utang lancar }\end{array}$ & $\frac{\text { Antiva Lancar }}{\text { Utang Lancer }}$ & Pasio & \begin{tabular}{|l} 
Erari \\
(2014)
\end{tabular} \\
\hline TATO & $\begin{array}{l}\text { Pasio jang } \\
\text { memibag } \\
\text { penjusian } \\
\text { dengan total } \\
\text { altiva }\end{array}$ & $\frac{\text { Fenjualan }}{\text { Total Aiktiva }}$ & Pasio & $\begin{array}{l}\text { Hasibuan } \\
\text { (2018) }\end{array}$ \\
\hline PER. & $\begin{array}{l}\text { Rasio yang } \\
\text { membeg nila } \\
\text { sabam dengan } \\
\text { laba per saharm }\end{array}$ & $\frac{\text { Nlai saham }}{\text { Laha per Saham }}$ & Pasio & $\begin{array}{l}\text { Anisa, X } \\
\text { (2015) }\end{array}$ \\
\hline DER & $\begin{array}{l}\text { Pasio yang } \\
\text { membag debt } \\
\text { dengan equity }\end{array}$ & $\frac{\text { Total Delat }}{\text { Total Equity }}$ & Pasio & $\begin{array}{l}\text { Asmi } \\
(2014)\end{array}$ \\
\hline
\end{tabular}

\section{Metode Analisis Data}

Analisis data menggunakan analisis regresi berganda. Bertujuan untuk mengetahui hubungan antara variabel bebas dengan variabel terikat secara simultan maupun secara parsial. Dalam hal ini untuk variabel dependennya adalah return saham dan variabel independennya CR, TATO, PER, dan DER.

\section{HASIL DAN PEMBAHASAN Hasil Penelitian}

Penelitian ini menggunakan sampel sebanyak 88 data dengan statistik deskriptif sebagai berikut:

Tabel 2. Statistik Deskriptif

\begin{tabular}{|c|c|c|c|}
\hline Variabel & Minimum & Maksimum & Mean \\
\hline $\begin{array}{c}\text { Return } \\
\text { Saham }\end{array}$ & 88 &,- 605 & 2,344 \\
\hline CR & 88 &, 246 & 314,027 \\
\hline TATO & 88 &, 004 &, 717 \\
\hline PER & 88 & $-266,130$ & 2611,580 \\
\hline DER & 88 &, 030 & 624,960 \\
\hline
\end{tabular}

Return saham menunjukan nilai rata - rata 0,02930 atau $0,2 \%$ sedangkan standar deviasi sebesar 0,405486 atau $40 \%$ (nilai rata - rata lebih kecil dari standar deviasi) artinya return saham memiliki tingkat variasi data yang rendah. Current Ratio (CR) menunjukan nilai rata - rata 41,87034 sedangkan standar deviasi sebesar 57,343239 (nilai rata - rata lebih kecil dari standar deviasi) artinya current ratio memiliki tingkat variasi data yang rendah. Total Asset Turnover (TATO) menunjukan nilai rata rata 0,18226 sedangkan standar deviasi sebesar 0,117759 (nilai rata - rata lebih kecil dari standar deviasi) artinya total asset turnover memiliki tingkat variasi data yang rendah.

\section{Uji $t$}

Uji statistik $t$ dilakukan dengan tujuan mengetahui besarnya pengaruh variabel independen secara parsial dengan variabel dependen. Jika hasil output regresi menghasilkan nilai sig < 0,05 maka secara individual variabel independen tersebut berpengaruh terhadap variabel dependen. Besarnya 
hubungan dapat dilihat pada kolom koefisien.

\begin{tabular}{|l|c|l|}
\multicolumn{4}{|c|}{ Tabel 3. Hasil Uji t } \\
\begin{tabular}{|l|c|l|}
\hline \multicolumn{1}{|c|}{ Var } \\
Independent
\end{tabular} & P. Value & \multicolumn{1}{c|}{ Hasil } \\
\hline $\begin{array}{l}\text { Current } \\
\text { Ratio }\end{array}$ & $0,066>0,05$ & $\begin{array}{l}\text { Tidak } \\
\text { berpengaruh } \\
\text { terhadap return } \\
\text { saham }\end{array}$ \\
\hline $\begin{array}{l}\text { Total Asset } \\
\text { Turn Over }\end{array}$ & $0,073>0,05$ & $\begin{array}{l}\text { Tidak } \\
\text { berpengaruh } \\
\text { terhadap return } \\
\text { saham }\end{array}$ \\
\hline $\begin{array}{l}\text { Price } \\
\text { Earning } \\
\text { Ratio }\end{array}$ & $0,017<0,05$ & $\begin{array}{l}\text { Berpengaruh } \\
\text { terhadap return } \\
\text { saham }\end{array}$ \\
\hline $\begin{array}{l}\text { Debt to } \\
\text { Equity Ratio }\end{array}$ & $0,000<0,05$ & $\begin{array}{l}\text { Berpengaruh } \\
\text { terhadap return } \\
\text { saham }\end{array}$ \\
\hline
\end{tabular}

\section{Pembahasan \\ Pengaruh Current Ratio terhadap Return saham}

Hasil analisis ini menunjukan bahwa current ratio (rasio lancar) tidak berpengaruh terhadap return saham hal ini sejalan dengan hasil penelitian yang dilakukan oleh Tumonggor et al. (2017), Nurmasari (2015), Basalama et al. (2016), Fajri \& Dewi (2018), Lestari et al. (2015), Ramadhan (2017), Putriani \& Sukartha (2014) yang mengemukakan bahwa current ratio tidak berpengaruh terhadap return saham. Dikarenakan nilai current ratio yang tinggi menunjukkan bahwa ketersediaan aktiva lancar guna melunasi kewajiban lancar juga tinggi. Sedangkan aktiva lancar berisi akunakun seperti kas dan setara kas, piutang, persediaan, dan surat berharga. Namun dengan tingginya current ratio belum tentu menjamin perusahaan mempunyai cukup kas untuk memenuhi kewajiban lancarnya.

\section{Pengaruh Total Asset Turnover Terhadap Return saham}

Hasil analisis ini menunjukan bahwa total asset turnover tidak berpengaruh terhadap return saham hal ini sejalan dengan hasil penelitian yang dilakukan oleh Sulaiman (2015), Lestari et al. (2015), Septiana \& Wahyuati (2016), Ramadhan (2017), Putriani \& Sukartha (2014), yang mengemukakan bahwa total asset turnover tidak berpengaruh terhadap return saham, dikarenakan variabel Total Asset Turn Over (TATO) dalam penelitian ini tidak berpengaruh terhadap return saham, karena dapat diketahui bahwa perusahaan dalam pemanfaatan keseluruhan aktiva tidak digunakan secara baik dan efektif. Sehingga, hal ini dapat mempengaruhi proses produksi dan penjualan dalam menghasilkan laba.

\section{Pengaruh Price Earning Ratio Terhadap Return Saham}

Hasil analisis ini menunjukan bahwa Price Earning Ratio (PER) berpengaruh terhadap return saham hal ini sejalan dengan hasil penelitian yang dilakukan Andansari et al. (2016), Mutia \& Martaseli (2018), Dewi (2017), Dewi et al. (2016), Sodikin \& Wuldani, (2017) Kesediaan investor membayar lembar saham dalam jumlah tertentu dengan mengharapkan memperoleh laba perusahaan digambarkan oleh Price Earning Ratio (PER). Tingginya nilai rasio ini menandakan dana yang telah dikeluarkan investor dimana para investor meyakini bahwa perusahaan memiliki pertumbuhan yang tinggi, yang tentunya akan berdampak terhadap perolehan keuntungan (return) yang besar juga untuk investor dan pertumbuhan dan kinerja perusahaan cukup baik, investor akan tertarik untuk melalukan investasi di perusahaan karena melihat hal ini.

\section{Pengaruh Debt to Equity Ratio terhadap Return Saham}

Hasil analisis ini menunjukan bahwa debt to equity ratio berpengaruh terhadap return saham Hal ini sejalan dengan penelitian yang dilakukan oleh Sutriani (2014), Erari (2014), Hidayat \& Nur (2016), Basalama et al. (2016), Raningsih \& Putra (2015), Handayati \& Zulyanti (2018), Asmi (2014), Ramadhan (2017), Putriani \& Sukartha (2014), Para investor cenderung menghindari sahamsaham yang memiliki DER yang tinggi, karena tingginya nilai DER menunjukkan bahwa struktur permodalan usaha lebih banyak memanfaatkan hutang-hutang relatif terhadap ekuitas. Semakin tinggi DER mencerminkan risiko perusahaan yang relatif tinggi. Kinerja perusahaan 
yang dipengaruhi oleh Debt to Equity Ratio (DER) menyebabkan apresiasi harga saham. Nilai DER yang terlalu tinggi berdampak buruk terhadap kinerja pe-rusahaan, dikarenakan hutang yang semakin tinggi menunjukkan beban bunga perusahaan akan semakin besar dan mengurangi keuntungan. Sehingga semakin tinggi hutang (DER) cenderung menurunkan return saham.

\section{KESIMPULAN \\ Kesimpulan}

Dari hasil penelitian ini dapat disimpulkan bahwa terdapat dua variabel independen yang mempengaruhi return saham yaitu price earning ratio $\left(\mathrm{X}_{3}\right)$ dan debt to equity ratio $\left(\mathrm{X}_{4}\right)$ yang dinyatakan bahwa price earning ratio $\left(\mathrm{X}_{3}\right)$ dan debt to equity ratio $\left(\mathrm{X}_{4}\right)$ berpengaruh terhadap return saham secara positif, tetapi return saham tidak dipengaruhi oleh dua variabel independen lainnya yaitu current ratio $\left(\mathrm{X}_{1}\right)$ dan total asset turnover $\left(\mathrm{X}_{2}\right)$ terhadap return saham pada perusahaan properti yang tergabung dalam ISSI.

\section{Saran}

Perusahaan diharapkan dapat lebih memperhatikan rasio-rasio keuangan sebelum melakukan kebijakan dalam menjual saham, yang dapat menarik minat para investor.

\section{DAFTAR PUSTAKA}

Andansari, N. A., Raharjo, K., \& Andini, R. (2016). Pengaruh Return On Equity (ROE), Price Earning Ratio (PER), Total Asset Turn Over (TATO) dan Price to Book Value (PBV) terhadap Return Saham (Studi Kasus pada Perusahaan Manufaktur Sektor Makanan dan Minuman yang Terdaftar di BEI Periode 2008-2014). Journal of Accounting, 2(2).

Asmi, T. L. (2014). Current Ratio, Debt to Equity Ratio, Total Asset Turnover, Return on Asset, Price to Book Value sebagai Faktor Penentu Return Saham.
Basalama, I., Murni, S., \& Sumarauw, J. S. (2017). Pengaruh Current Ratio, DER dan ROA terhadap Return Saham pada Perusahaan Automotif dan Komponen Periode 2013-2015. Jurnal EM-BA: Jurnal Riset Ekonomi, Manajemen, Bisnis dan Akuntansi, 5(2).

Bursa Efek Indonesia website: http://www.idx.co.id/

Dewi, P. A. R., Sedana, I. B. P., \& Artini, L. G. S. (2016). Pengaruh Tingkat Suku Bunga, Risiko Pasar, Debt to Equity Ratio, dan Price Earning Ratio terhadap Return Saham pada Perusahaan Properti and Real Estate di Bursa Efek Indonesia. EJurnal Ekonomi dan Bisnis Universitas Udayana, 5(3).

Dewi, P. E. D. M. (2017). Pengaruh Rasio Likuiditas, Profitabilitas, Solvabilitas, Aktivitas, dan Penilaian Pasar terhadap Return Saham. JIA (Jurnal Ilmiah Akuntansi), 1(2).

Erari, A. (2014). Analisis Pengaruh Current Ratio, Debt to Equity Ratio, dan Return On Asset terhadap Return Saham pada Perusahaan Pertambangan di Bursa Efek Indonesia. Jurnal Manajemen Bisnis, 5(2).

Fajri, I., \& Dewi, S. A. (2018). Analisis Likuiditas, Profitabilitas, dan Return Saham pada Perusahaan Manufaktur di Indonesia.

Handayati, R., \& Zulyanti, N.R. (2018). Pengaruh Earning per Share (EPS), Debt to Equity Ratio, (DER), dan Return on Assets (ROA) terhadap Return Saham pada Perusahaan Manufaktur yang Terdaftar di BEI.

Hasibuan, M. Z. (2018). Analisis Pengaruh Rasio Keuangan terhadap Return Saham dengan Tingkat Debt to Equity Ratio Perubahan Kurs dan Tingkat Suku Bunga sebagai Variabel Moderating (Empiris pada Perusahaan Manufaktur yang Terdaftar di Bursa Efek Indonesia). Jurnal BisA: Jurnal Bisnis Administrasi, 7(1), 01-08.

Hidayat, I., \& Indrihastuti, P. (2016). Analisis Rasio Keuangan terhadap 
Return Saham pada Jakarta Islamic Index (JII) yang Terdaftar di BEI.

Hidayat., \& Nur, R. N. (2016). Pengaruh Debt to Equity Ratio (DER) dan Return on Asset (ROA) terhadap Return Saham Perusahaan Sektor Pertambangan di BEI.

Lestari, K., Andini, R., \& Oemar, A. (2015). Analisis Likuiditas, Leverage, Profitabilitas, Aktivitas, Ukuran Perusahaan, dan Penilaian Pasar terhadap Return Saham pada Perusahaan Real Estate dan Property di BEI.

Mutia, E., \& Martaseli, E. (2018). Pengaruh Price Earning Ratio (PER) terhadap Return Saham pada Perusahaan Manufaktur yang Terdaftar di Bursa Efek Indonesia (BEI) Periode 2010-2017. Jurnal Ilmiah Ilmu Ekonomi (Jurnal Akuntansi, Pajak dan Manajemen), 7(13), 78-91.

Nurmasari, I. (2015). Analisis Current Ratio, Return on Equity, Debt to Equity Ratio, dan Pertumbuhan Pendapatan Berpengaruh terhadap Return Saham pada Perusahaan Pertambangan di BEI.

Putriani, N. P, \& Sukartha, I. M. (2014). Pengaruh Rasio Keuangan terhadap Return Saham Perusahaan LQ-45.

Ramadhan, F. (2017). Pengaruh Rasio Keuangan terhadap Return Saham BUMN Sektor Pertambangan di BEI.

Raningsih, N. K., \& Putra, I. M. P. D. (2015) Pengaruh Rasio-rasio Keuangan dan Ukuran Perusahaan pada ReturnSsaham.

Septiana, F. E., \& Wahyuati, A. (2016). Pengaruh Rasio Keuangan terhadap Return Saham pada Perusahaan Manufaktur. Jurnal Ilmu dan Riset Manajemen, 5(1), 2461-0593.

Sodikin, S., \& Wuldani, N. (2017). Pengaruh Price Earning Ratio (PER) dan Earning per Share (EPS) terhadap Return Saham (Studi pada PT. Unilever Indonesia Tbk). Jurnal Ekonomi Manajemen, 2(1), 18-25.
Sulaiman, B. (2015). Pengaruh Rasio Likuiditas, Leverage, Rasio Aktivitas, dan Rasio Profitabilitas pada Perusahaan dalam Katagori Industri Barang Konsumsi di BEI.

Sutriani, A. (2014). Pengaruh Profitabilitas, Leverage, dan Likuiditas terhadap Return Saham dengan Nilai Tukar Sebagai Variabel Moderasi pada Saham LQ45. Journal of Business and Banking, 4(1), 67-68.

Tumonggor, M., Murni, S., \& Van Rate, P. (2017). Analisis Pengaruh Current Ratio, Return on Equity, Debt to Equity Ratio, dan Growth terhadap Return Saham pada Cosmetics and Household Industry yang Terdaftar di BEI Periode 2010-2016. Jurnal EMBA: Jurnal Riset Ekonomi, Manajemen, Bisnis dan Akuntansi, $5(2)$. 